\title{
Tourism in the Pamir-Alai Mountains, Southern Kyrgyz Republic
}

\author{
キルギス南部，パミール・アライ山脈のツーリズム
}

\author{
Teiji WATANABE*, Maksat ANARBAEV**, Yasuhiro OCHIAI***, \\ Shigeyuki IZUMIYAMA $* * *$ and Lebaiatelaite GAUNAVINAKA***** \\ 渡辺 悌二**マ・クサト アナルバエフ**・落合 康浩***. \\ 泉山 茂之****・レンバイアテライテ ガウナビナカ
}

Key words : The Kyrgyz Republic, Pamir-Alai Mountains, tourism development, sustainability キーワード：キルギス共和国，パミール・アライ山脈，ツーリズム開発，持続性

\begin{abstract}
要旨
キルギス共和国南部のパミール・アライ山脈地域において, ッーリズムの現状を明らかにし，その問題点を指摘した。 現地では 7 つ村で合計514世帯にアンケート用紙を配布し，354世帯から回答を得た。また，地元関係者に対して聞き取 り調査を行った。その結果，90\%以上の回答者がッーリズム開発を望んでいることがわかった。この地域では, 旧ソ連邦 時代からレーニン峰やベースキャンプヘの登山・トレッキングッアーが実施されてきたが, 現在でもその多くがウズベ キスタンをはじめとする周辺諸国の観光・トレッキング会社によって行われており，収入のほとんどが地元に還元されな い仕組みができている。最近になって，アライ谷東部のサリタシ村とサリモゴル村に，ユルト（移動式のフェルト製テン ト）や民家を使ったきわめて小規模なツーリズム施設が散見されるようになってきた。しかし，そこでもたらされる収入 は，きわめて限られた世帯にしかもたらされない。ほとんどの住民が, ッーリズム開発を推進させる鍵として地方空港や ホテル建設，道路整備などを期待している。しかし，外部資本が開発を始める前に地元にエコッーリズム関連の組織を設 立する必要があると考えられる。この組織は, ッーリズム開発による収入の多くを地元に落とす役割を果たすだけではな く，不必要な開発を抑制し自然資源保全にも結びつく役割を果たし得る。その結果，この地域の持続性が高まると期待さ れる。
\end{abstract}

\section{I . Introduction}

The Kyrgyz Republic is a mountainous Central Asian country. Further, the Kyrgyz Republic proposed the International Year of Mountains 2002 (IYM 2002). The country's geography is dominated by the Tien Shan Mountains and the Pamir-Alai Mountains. Mountain tourism is a recent idea in the Kyrgyz Republic though there was a fledgling mountain tourism industry even when the country was a Soviet Republic (Schneider and Stadelbauer, 2008) In fact, the Law of Tourism was created as recently as 1999 and the State Agency of Tourism was established in April 2007.

The area that the present-day Kyrgyz Republic occupies has been regarded as marginal since the times of the Soviet Union and has essentially functioned as an agricultural and pastoral area.

\footnotetext{
*Faculty of Environmental Earth Science, Hokkaido University, Japan／北海道大学地球環境科学研究院

**National Center for Mountain Regions Development, The Kyrgyz Republic／キルギス国立山岳地域開発研究センター

*** Collage of Humanities and Sciences, Nihon University, Japan/日本大学文理学部

****Faculty of Agriculture, Shinshu University, Japan/信州大学農学部

*****Graduate School of Environmental Science, Hokkaido University, Japan/北海道大学環境科学院 ·院生
} 
Schneider and Stadelbauer (2008) give an overview of the tourism in the country, emphasizing the diversity in mountain tourism. Tourism development, however, is limited mostly to the eastern part of the country - the Isykukul (Ysyk-köl) Lake area. Thus, studies on tourism in the Kyrgyz Republic are extremely limited, being mostly conducted in the eastern part of the country.

This study outlines the current status of tourism in the Pamir-Alai Mountains area, the southernmost area of the country and discusses the current problems faced by the tourism sector in the area. The study area was selected because the following two projects are in progress: the UNU/ GEF/UNEP project for Sustainable Land Management in the High Pamir and Pamir-Alai Mountains (PALM) (CDE, 2005; Hannam, 2006; Jansky and Pachova, 2006) and the Pamir-Alai Transboundary Conservancy Area (PATCA) project (AGRECO Consortium, 2007; Watanabe and Kasirov, 2007; Baird, 2008).

\section{II . Study Area}

The Pamir-Alai Mountains are located in the southernmost region of the country, bordering the Republic of Tajikistan (Fig. 1). This is the most remote area of the country and farthest from the capital city of Bishkek; hence, economic development lags far behind the rest of the country and tourism is no exception.

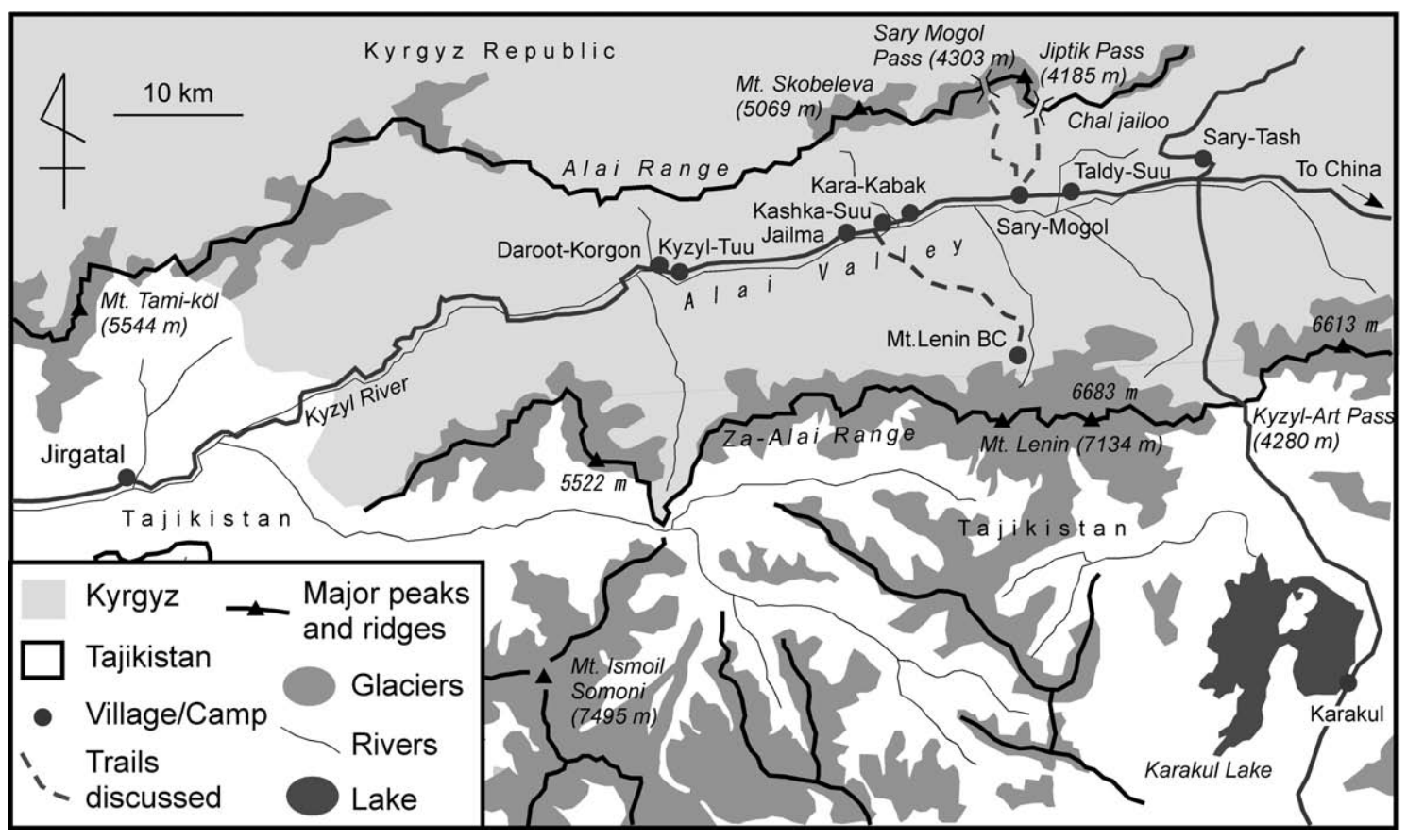

Fig. 1. The study area.

Kyrgyz schools normally teach students that the Alai Range is a part of the Pamir-Alai Mountains, although the range has been traditionally included in the Tien Shan Mountains (Azykova, 2002). Iwata (2008) describes the Alai Range as a component of the Pamir-Alai Mountains based on its geographical settings. This study, therefore, defines that the Pamir-Alai Mountains consist of the Alai and Za-Alai ranges. Mt. Lenin: 38²0'37"N, $72^{\circ} 52^{\prime} 40^{\prime E} \mathrm{E}$; M. Ismoil Somoni: 3856'36"N, 7200'57"E. Broken lines: existing major trekking routes.

The Pamir-Alai Mountains consist of two ranges - the Alai Range in the north and the Za-Alai Range in the south (Fig. 1). The Alai Range has peaks and ridges reaching 4,000-5,000 m with the 
highest peak Mt. Tami-Köl (Mt. Tamai-Köl) towering at 5,544 m. The mountain range is covered with small glaciers. The Za-Alai Range, often referred to as the Trans Alai Range by westerners, is characterized by glacierized peaks and ridges that are often $6,000 \mathrm{~m}$ high with the highest peak Mt. Lenin reaching 7,134 m. The eastern part of the Za-Alai Range is often referred to as the Alai Range and the western part, as the Chon-Alai Range; this is in line with the nomenclature of the Alai District and the Chon-Alai District, administrative divisions that are spanned by the Za-Alai Range.

The valley between the Alai and $\mathrm{Za}$-Alai ranges is known as the Alai Valley. The valley floor is a vast grazing land for yaks, sheep, goats and horses and is dotted with small studded villages. The nomadic lifestyle of the people in the country changed dramatically with the Russian conquest and later evolved into a system of transhumance (Schillhorn van Veen, 1995); consequently, the number of nomads in the Allai Valley seems to have decreased and transhumance herders are dominant in the valley.

The Sary-Tash village, located at an altitude of 3,160 $\mathrm{m}$ in the upper valley, cannot support any agricultural product because it experiences severe winter climate. On the other hand, the DarootKorgon (Kargon) village located at 2,480 $\mathrm{m}$ is able to support a variety of agricultural products. The agricultural products grown in the Kashka-Suu village $(2,800 \mathrm{~m})$, located in the central area of the valley, include potato, wheat and barley.

\section{Method}

A preliminary survey was conducted in July and August 2008. Interviews with local residents and local tourism-related individuals were conducted mainly in Sary-Tash and Sary-Mogol, where there is some tourism activity. Additional interviews were conducted in some other villages as well.

The questionnaire survey contained 16 questions and was conducted in October and November 2008. The questionnaire was first prepared in English and then translated into Kyrgyz. A total of 514 translated questionnaire sheets were distributed across seven schools in the villages of SaryTash, Sary-Mogol, Kara-Kabak, Kashka-Suu, Jailma, Kyzyl-Tuu and Daroot-Korgon (Fig. 1). School children took the questionnaire sheets home to get them filled by their parents. We received 354 answer sheets but some of these were incomplete.

Of the 354 respondents, 82 were public officers; 73, farmers/pastoral herders; 36, private-sector employees; 26, construction workers; 5 , service personnel and 37 were engaged in other occupations. Further, 95 respondents did not give any answer. The percentages of male and female respondents were $71.4 \%$ and $28.6 \%$, respectively. A significant percentage $(47.2 \%)$ of the respondents were in their teens; this is because many students incorrectly filled-in their ages while questioning their parents. Further, $16.1 \%$ of the respondents were in their twenties; $17.7 \%$, in their thirties; $13.0 \%$, in their forties; $5.0 \%$, in their fifties and $0.9 \%$ were aged sixty or above.

\section{Results}

1. Tourism activities, destinations and resource usage

The area is visited by individual tourists and group tourists. Most individual tourists visit the area while cycling from Osh to Murgab in Tajikistan and vice versa (Photo 1). Sary-Tash is the only place where these individual tourists stay overnight. The number of group tourists is higher. Most group tourists visiting the Mt. Lenin Base Camp (also referred to as the Achik-Tash Base Camp) do so for mountain climbing and trekking purposes. Some individual and group tourists stay in Sary-Tash 
while travelling from China or Tajikistan and vice versa.

Even during the Soviet times, trekking and climbing were common in the Mt. Lenin Base Camp area. Sawagaki (2008) described the base camp area in 1987 when he climbed Mt. Lenin as follows: the active and effective support programmes for foreign climbers had been well organized at that time and they even seem to have been better than today. The Mt. Lenin Base Camp area is still the centre of the trekking and climbing tourism programmes in the area.

Community-Based Tourism (CBT) opened its branch office in Sary-Mogol in 2006 (Photo 2). CBT was established in the country with the support of Switzerland in 2002 and was registered in 2003 (Kyrgyz Community-Based Tourism Association, 2006). The branch office hired three guides, who then attended a seminar and sat for an examination, following which they were certified by the Kyrgyz Community-Based Tourism Association (KCBTA in English and KATOS in Kyrgyz). The CBT branch office offers short trekking programmes in three trekking courses (Fig. 1): (1) Mt. Lenin Base Camp, (2) Jiptik Pass (4,185 m by 1:500,000 Soviet map; 4, 175 $\mathrm{m}$ by 1:100,000 Soviet map) and (3) Sary-Mogol Pass (4,303 m by 1:500,000 Soviet map; 4,270 m

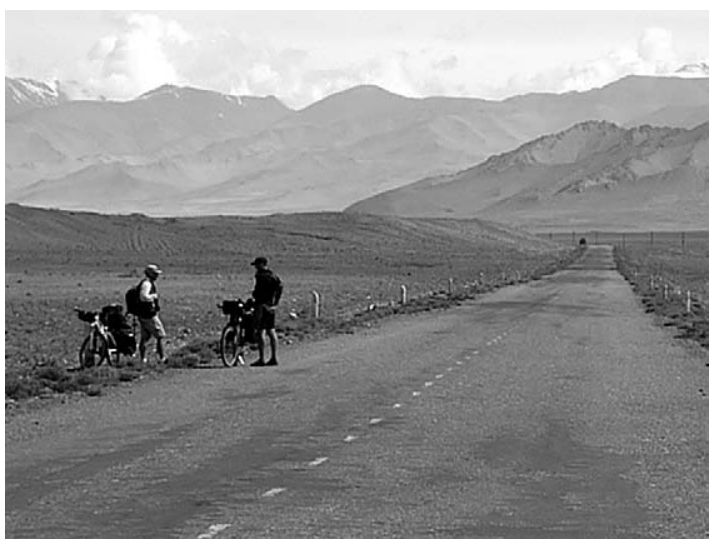

Photo 1. Cyclists visiting the Takij Pamirs through Sary-Tash (Photo: Watanabe, 6 August 2007).

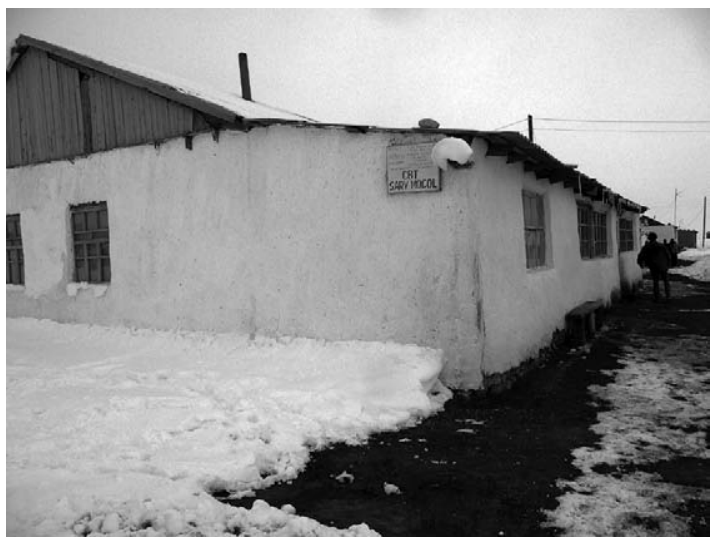

Photo 2. CBT branch office and homestay in SaryMogol (Photo: Watanabe, 13 November 2008). by $1: 100,000$ Soviet map).

On these treks, the guides are able to provide basic information pertaining to the regional birds (especially raptors), marmots and ibexes, as and when encountered. These guides also display some knowledge about trees and flowers but the head of the office mentioned that this knowledge was merely limited to the nomenclature of edelweiss. Further, the guides and some tourists witnessed the damage caused to edelweiss in the Mt. Lenin Base Camp. The guides show their clients the lakes in the Mt. Lenin Base Camp area, but make no mention about landforms such as moraines and faults. Other abiotic natural resources in this area include a hogback (a structural landform) near Daroot-Korgon and tarns (cirque lakes), moraines and rock glaciers in the Alai Range. Our interview survey with all tourism-related individuals in the area clarified that these abiotic natural resources of interpretive importance to tourists are never explained by the guides to the tourists. Moreover, our conversation with many local residents suggests that the local residents do not have any knowledge about the landforms in the area, although some did provide accounts of large earthquakes in the past and coal mining activity in the area. 


\section{Current status and development of tourism infrastructure}

There are no tourism facilities, such as hotels, lodges and visitor centres, except three 'homestays' in Sary-Tash and Sary-Mogol and three yurts, or movable field tents used by nomads and herders, in Sary-Tash and the Mt. Lenin Base Camp (Photo 3). The TaldySuu village has been attempting to develop yurt tourism. They applied for funding with the Community Development and Investment Agency of the Kyrgyz Republic (ARIS) and the Asian Development Bank (ADB) in 2006-2007 to develop a chal yurt camp in a kishtoo (winter pasture) in the north-eastern area of the

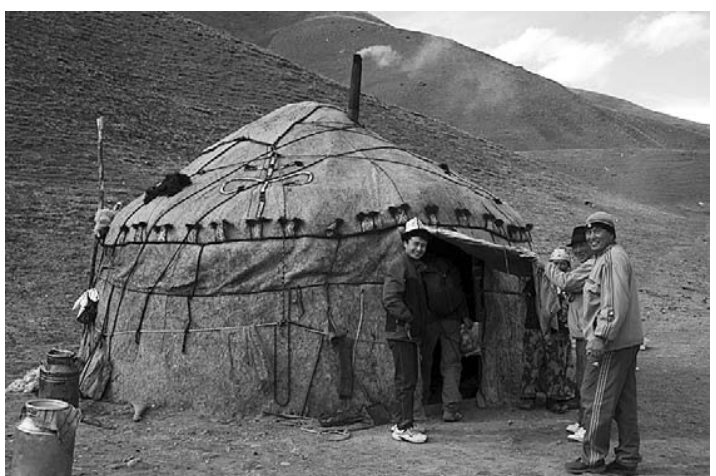

Photo 3. Yurt at the Mt. Lenin Base Camp (Photo: Watanabe, 13 October 2006). community. The village has not received any funding yet, and as such, there is no yurt in TaldySuu thus far. No villages in the Alai Valley have tourism-related associations or an independent administrative section handling tourism.

Sary-Tash, the central village in the eastern (upper) area of the Alai Valley, has two homestays (Photo 4) and two family-run yurts. One of the homestays provides accommodation to tourists at Som 300 per person per night (Som 41 = USD 1.00 in March 2009) and the other charges Som 150 per person per night. The former homestay began operations in 2006 and had less than a hundred guests in both 2006 and 2007. The family entered into a contract with a tour company based in Osh, and as such, the number of guests increased to more than 500 in 2008. One of the yurts started operations in 2004.

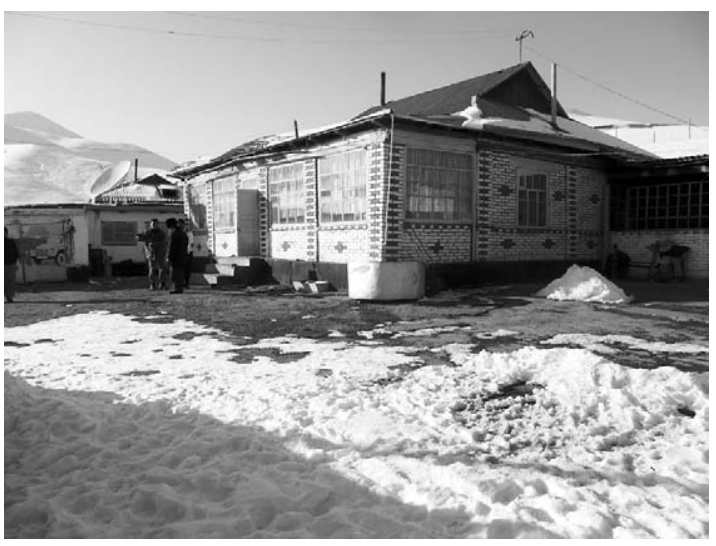

Photo 4. Homestay in Sary-Tash (Photo: Watanabe, 19 November 2008). Further, the number of guests was only 25-30 in 2004, 50-60 in 2005 and approximately 150 in 2007. The family has contracts with three tour/trekking companies in Bishkek (Kyrgyz Concept, CBT and Edelweiss). Most of the guests visit the Mt. Lenin Base Camp and then move to China or Tajikistan. The other yurt began operations in 2008 and has clients mainly through Bishkek-based and Osh-based tour companies, along with some clients in the form of individual cyclists. The Agency for Technical Cooperation and Development (ACTED), a French NGO that aims at poverty reduction in the southern Kyrgyz and consequently launched an ecotourism project in the Tajik Pamir, also has a branch office in Sary-Tash.

Sary-Mogol is another village that has a primitive tourism facility run by the CBT. The CBT branch office in Sary-Mogol opened a homestay in May 2006 (Photo 2). The number of guests was 50-60 in 2006, approximately 150 in 2007 and approximately 200 in 2008. In 2008, tourists from 10 countries including France, Switzerland and Germany, visited the place. 
3. Local residents' views with regard to the necessity and preference of tourism infrastructure development

Most of the respondents (245/256; 95.7\%) felt that tourism infrastructure development in the Pamir-Alai Mountains area is necessary (Fig. 2a). Most respondents (318/338; 91.4\%) also expressed their willingness to participate in tourism development (Fig. 2b). Moreover, 77.4\% (257/332) of the respondents expressed their willingness to work as tour guides for foreigners in the future (Fig. 2c). These numbers indicate that the local society, much like the central government, earnestly looks forward to tourism development. Most respondents, however, are unfamiliar with English (68.2\%)although 83.1\% mentioned that they are fluent in Russian (Fig. $2 \mathrm{~d}$ and e).

Figure 3 illustrates the residents' views with regard to the suggested tourism infrastructure development initiatives in this area. Most of the residents regarded all the seven suggested initiatives as necessary. Although many residents and government officers often emphasize the necessity of improving the road connecting Osh and this region, the respondents believed that an airport is of utmost importance for tourism development (Fig. 3b), followed by the establishment of a tour guide association (Fig. 3g).

Table 1 shows the residents' preferences with regard to various tourism activities that should be developed in the region. The percentage figures were converted into index values (IVs) to illustrate the relative strength of the preferences. IVs are calculated as follows: 2(the

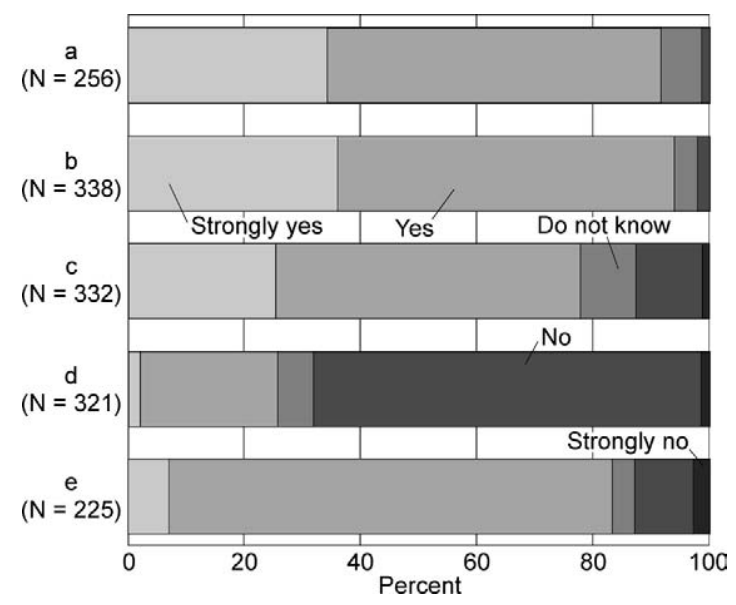

Fig. 2. Residents' views with regard to the necessity of tourism development in the study area and familiarity with English and Russian. a-e: see text. Data derived from a questionnaire survey done in 2008.

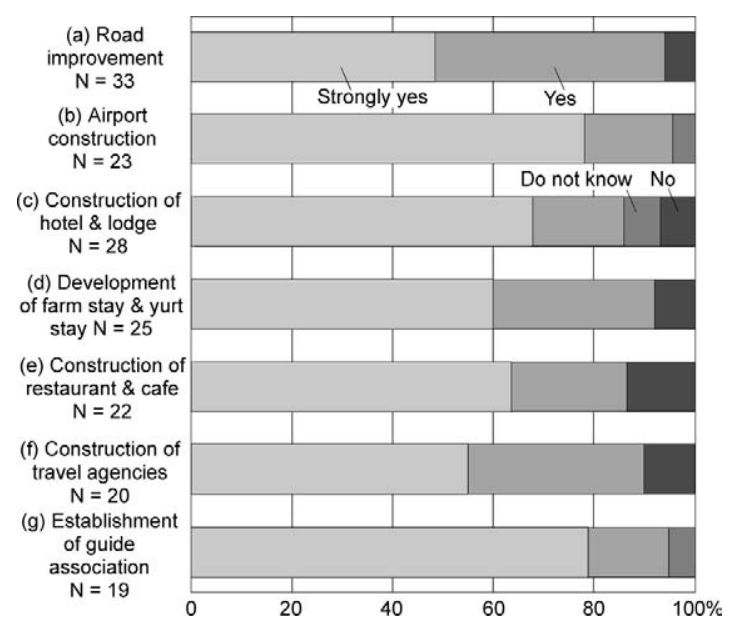

Fig. 3. Residents' views with regard to the tourism development initiatives in the study area. Data derived from a questionnaire survey done in 2008. percentage of respondents who replied 'strongly yes') + (the percentage of respondents who replied 'yes') - (the percentage of people who replied 'no') -2 (the percentage of people who replied 'strongly no'). Note that the larger the IV, the stronger the residents' preference. The respondents regard cultural and social activities such as visiting and staying in yurts $(\mathrm{IV}=130)$, visiting and staying in farmland and grazing land accommodation (IV=104) and learning and experiencing traditional customs and culture (IV=100) as important. The largest tourism activity in the area is mountain climbing and trekking. Nevertheless, $12.5 \%$ of the respondents gave a negative response in this regard (Table 1d). The lower IV for mountain climbing 
Table 1. Residents' preferences with regard to various tourism activities that should be developed in the region (percentage figures in the upper rows; IVs in italics in the lower rows).

\begin{tabular}{|c|c|c|c|c|c|c|}
\hline & Strongly yes & Yes & Do not know & No & Strongly no & Total \\
\hline \multirow{2}{*}{$\begin{array}{l}\text { (a) Staying in/visiting yurt } \\
\qquad(\mathrm{N}=20)\end{array}$} & $40.0 \%$ & $55.0 \%$ & $0.0 \%$ & $5.0 \%$ & $0.0 \%$ & $100.0 \%$ \\
\hline & 80 & 55 & 0 & -5 & 0 & 130 \\
\hline \multirow{2}{*}{$\begin{array}{l}\text { (b) Visiting farmland \& grazing } \\
\text { land } \\
(\mathrm{N}=24)\end{array}$} & $33.3 \%$ & $45.8 \%$ & $12.6 \%$ & $8.3 \%$ & $0.0 \%$ & $100.0 \%$ \\
\hline & 67 & 46 & 0 & -8 & 0 & 104 \\
\hline \multirow{2}{*}{$\begin{array}{l}\text { (c) Learning \& experiencing } \\
\text { traditional customs \& culture } \\
\qquad(\mathrm{N}=21)\end{array}$} & $38.1 \%$ & $38.1 \%$ & $9.5 \%$ & $14.3 \%$ & $0.0 \%$ & $100.0 \%$ \\
\hline & 76 & 38 & 0 & -14 & 0 & 100 \\
\hline \multirow{2}{*}{$\begin{array}{l}\text { (d) Mountain climbing \& trekking } \\
\qquad(\mathrm{N}=24)\end{array}$} & $20.8 \%$ & $66.7 \%$ & $0.0 \%$ & $4.2 \%$ & $8.3 \%$ & $100.0 \%$ \\
\hline & 42 & 67 & 0 & -4 & -17 & 88 \\
\hline \multirow{2}{*}{$\begin{array}{l}\text { (e) Horse riding tours/safaris } \\
(\mathrm{N}=17)\end{array}$} & $11.8 \%$ & $58.8 \%$ & $5.9 \%$ & $17.6 \%$ & $5.9 \%$ & $100.0 \%$ \\
\hline & 24 & 59 & 0 & -18 & -12 & 53 \\
\hline \multirow{2}{*}{$\begin{array}{l}\text { (f) Wildlife watching } \\
(\mathrm{N}=17)\end{array}$} & $17.6 \%$ & $47.1 \%$ & $0.0 \%$ & $29.4 \%$ & $5.9 \%$ & $100.0 \%$ \\
\hline & 35 & 47 & 0 & -29 & -12 & 41 \\
\hline \multirow{2}{*}{$\begin{array}{l}\text { (g) Skiing } \\
(\mathrm{N}=16)\end{array}$} & $18.8 \%$ & $37.5 \%$ & $0.0 \%$ & $43.7 \%$ & $0.0 \%$ & $100.0 \%$ \\
\hline & 38 & 38 & 0 & -44 & 0 & 31 \\
\hline \multirow{2}{*}{$\begin{array}{l}\text { (h) Yak riding tours/safaris } \\
(\mathrm{N}=13)\end{array}$} & $7.7 \%$ & $23.1 \%$ & $23.1 \%$ & $38.4 \%$ & $7.7 \%$ & $100.0 \%$ \\
\hline & 15 & 23 & 0 & -38 & -15 & -15 \\
\hline \multirow{2}{*}{$\begin{array}{l}\text { (i) Hunting wildlife } \\
(\mathrm{N}=17)\end{array}$} & $5.9 \%$ & $29.4 \%$ & $0.0 \%$ & $64.7 \%$ & $0.0 \%$ & $100.0 \%$ \\
\hline & 12 & 29 & 0 & -65 & 0 & -24 \\
\hline
\end{tabular}

Percentage figures are derived from a questionnaire survey. The IVs are calculated as follows: 2 (the percentage of residents who replied 'strongly yes') + (the percentage of residents who replied 'yes') - (the percentage of residents who replied 'no') - 2(the percentage of people who replied 'strongly no').

and trekking, as compared to that for learning and experiencing traditional customs and culture (Table 1c) for instance, may be because the villagers feel that climbing and trekking are not a part of their daily life.

The respondents believe that yak riding tours or yak safaris $(I V=-15)$, hunting wildlife $(I V=-$ 24), skiing (IV=31), wildlife watching (IV=41) and horse riding tours or horse safaris (IV=53) are less important (Table 1e-i). Further, majority of the respondents do not show any preference for yak riding tours, but favour horse riding tours. Thus, the necessity of developing horse riding tours is evidently high given that the region has a rich nomad tradition. On the other hand, however, the local residents' preference with regard to the development of yak riding tours is different from that of the residents in the Karakoram and Himalaya mountain ranges.

\section{Tourism income and monetary leakage}

An interview survey conducted in 2005 (Anarbaev, 2007) indicates that $80 \%$ of the group tourists who visited the Mt. Lenin Base Camp were guided by tour/trekking companies based in Uzbekistan; $15 \%$, by companies based in Russia or Kazakhstan and 5\%, by companies in the Kyrgyz Republic. The tourists visiting the Mt. Lenin Base Camp are mainly from Western Europe even though 63\% of the tourists visiting the Kyrgyz Republic are Kazakh (Watanabe et al., 2008). Our 2008 interview survey suggested that approximately 1,000 tourists visit the Mt. Lenin Base Camp every year and that 
these tourists are guided mainly by companies based in Uzbekistan, Kazakhstan and some domestic companies based in Bishkek, such as Tien Shan Travel, Asian Mountains, Edelweiss and Kyrgyz Concept (the former two companies cater to clientele that is looking for a more professional climbing and trekking experience) and a company based in Osh (Irkeston Tours). The companies use local yurts in Sary-Tash and the Mt. Lenin Base Camp area, through which some local residents obtain income. The companies hire local porters when they send some of their clients from the Mt. Lenin Base Camp to the so-called Camp 1 $(4,200 \mathrm{~m})$. The salary paid to the porters used to be USD1.00 per $\mathrm{kg}$ of load, but these days, this drops to USD0.4-0.5/kg, especially when Uzbek companies employ local porters. The total annual income of local porters is unknown but is speculated to be extremely limited. Further, because foreign companies bring all necessary materials including food from outside, most of the money derived from clients goes to foreign companies, resulting in income leakage. Because Kashka-Suu has no homestays, yurts, restaurants, or souvenir shops, the village has been loosing tourism income even though it is the entrance village for the Mt. Lenin Base Camp. The problem is that only $31.7 \%$ of the respondents $(\mathrm{N}=13)$ are aware of the fact that such foreign tour/ trekking companies bring foreign clients to the area while providing almost no money to the villages and only $47.4 \%(147 / 310)$ consider this a great concern.

Further, the income from the recently started tourism facilities in Sary-Tash and Sary-Mogol is extremely limited. One of the yurt in Sary-Tash charges Som 750 per person per night including breakfast and dinner. As described earlier, the annual total number of guests that this yurt received in 2007 was approximately 150; this implies annual proceeds of Som 112,500. The family has to purchase all food materials except for dairy products from Osh as no agricultural products are available in Sary-Tash. After the necessary expenses are subtracted from the annual proceeds, the family's annual income is found to be very small. Moreover, there is no income distribution to the surrounding families in the village.

The other yurt in Sary-Tash charges USD 18 per person per night including breakfast and dinner. Most guests stay for only one night and then proceed to China or Tajikistan. Only 10\% of the guests who visit the Mt. Lenin Base Camp stay in the area for two nights.

The CBT's branch office in Sary-Mogol offers accommodation at a homestay (Som 300 per person per night) and a yurt (Som 300 per person per night), breakfast (Som 100), lunch or dinner (Som 150), horse rentals (Som 450 per day), automobile services (Som 15 per km), porters (Som 400-450 per day) and guides (Som 500 per day). Note that only a small portion of the income that these tourists generated goes to the local guides and other local personnel-approximately Som 19,000 in all in 2008. Again, there is extremely limited income distribution to the villagers.

\section{Discussion}

Table 2 shows the percentage of residents who are satisfied with the current economic conditions of both their village and their family. The respondents in the eastern area (upper valley) tend to have a negative view of the current economic condition, whereas those in the western area (lower valley) tend to have a positive view. It is interesting that the eastern area with more negative views is in the initial stages of tourism infrastructure development. The eastern area has a geographical advantage in terms of tourism development-the eastern area comes midway between Osh, China and Tajikistan. Further, the central area may have the largest development potential because of its geographical

location as the entrance for the Mt. Lenin Base Camp. Moreover, the geographical setting and rich 
Table 2. Percentage of residents who are satisfied with the current economic condition of both their village and their family.

\begin{tabular}{|c|c|c|c|c|c|c|c|}
\hline \multirow[b]{2}{*}{ Area } & \multirow{2}{*}{$\begin{array}{l}\text { Number of } \\
\text { respondents }\end{array}$} & \multicolumn{6}{|c|}{ Percentage } \\
\hline & & $\begin{array}{c}\text { Strongly } \\
\text { yes }\end{array}$ & Yes & $\begin{array}{l}\text { Do not } \\
\text { know }\end{array}$ & No & $\begin{array}{c}\text { Strongly } \\
\text { no }\end{array}$ & Total \\
\hline \multicolumn{8}{|c|}{ a) Satisfied with the current economic condition of their village: } \\
\hline Eastern area & 105 & 8.6 & 49.5 & 3.8 & 37.1 & 1.0 & 100.0 \\
\hline Central area & 122 & 7.4 & 46.7 & 9.8 & 34.4 & 1.6 & 100.0 \\
\hline Western area & 167 & 40.7 & 32.3 & 4.2 & 22.8 & 0.0 & 100.0 \\
\hline \multicolumn{8}{|c|}{ b) Satisfied with the current economic condition of their family: } \\
\hline Eastern area & 105 & 17.1 & 38.1 & 1.0 & 42.9 & 1.0 & 100.0 \\
\hline Central area & 117 & 18.8 & 47.0 & 5.1 & 29.1 & 0.0 & 100.0 \\
\hline Western area & 114 & 10.5 & 62.3 & 1.8 & 25.4 & 0.0 & 100.0 \\
\hline
\end{tabular}

Eastern area: Sary-Tash and Sary-Mogol; Central area: Kara-Kabak, Kashka-Suu and Jailma; Western area: Chon Alai and Alai Cyu (Daroot-Korgon). Questionnaire survey conducted in 2008.

natural resources of these areas are adequate for the development of ecotourism rather than mass, luxurious tourism. It may be reasonable that initially, ecotourism development be prioritized in the eastern and central areas.

In the eastern and central areas between Sary-Tash and Kashka-Suu/Jailma, a few families have opened yurts. There are three homestays in the valley. The capacity of these accommodations, however, seems to be too small. In fact, one of the families running the yurt mentioned that the tour/ trekking companies asked the family to increase the number of yurts.

Such primitive facilities are not found in the Kashka-Suu village. Residents of Kashka-Suu hope to develop the fish industry, which may be a good way of boosting the local economy. However, it should be noted that natural resources in and around the village are of tourism importance. As described earlier, not only biotic natural resources but also abiotic natural resources such as glaciers, glacial landforms and geology are not utilized partly owing to the residents' lack of knowledge with regard to such resources. It is suggested that the local residents be first allowed to learn the value of local natural resources as ecotourism resources.

In addition, social/cultural resources are not well recognized as ecotourism resources that need to be developed. Note that since the collapse of the Soviet Union, the transhumance of the people in this area has changed; this will be discussed elsewhere. While the number of sheep and goats has been reducing, the number of yaks and horses has been increasing since 1992; this is supported by unpublished statistical data of the Chon Alai District, located in the western half of the Alai Valley. This suggests that domestic animals can be great ecotourism attractions and even the transformation in the residents' transhumance itself can be an important ecotourism resource.

These ecotourism resources whose importance most local residents do not recognize should be utilized by the local residents before outside enterprises attempt inappropriate tourism development. In this regard, local organizations where the local residents assume leadership are important. Such organizations may include a communal body in the local administrative office, an independent association of local guides and a local porter union.

Ecotourism development should focus on the involvement of local residents. The involvement of local residents includes operating yurts and farmland and grazing land accommodation, hotels, 
restaurants and tour companies and conducting tours. However, these require the local residents to learn English.

Meanwhile, many residents expect positive supportive effects of tourism infrastructure development bought by the construction of the local airport, hotels and other infrastructure and improvements in the road network (Fig. 3). Development work done by outside enterprises does not often bring benefits to the local communities. The local tourism-related organizations need to be established before allowing tourism development by outsiders, which may be inadequate and unnecessary. The local tourism-related organizations can develop a variety of trails to show and interpret the unutilized natural resources.

The tour/trekking companies based in the surrounding countries such as Uzbekistan collect foreign clients through the internet and through dealings with international travel companies. They send the clients by airplanes and large vehicles to the area (Photo 5), with all necessary equipment including tents. This complete package system enables foreign tourists to visit the area with almost no accommodation or local transportation measures (Anarbaev and Watanabe, 2008). As a result, the PamirAlai Mountains area has lost most of the money derived from the limited tourism in the area. The monetary leakage in the Mt. Lenin Base Camp area is a combined result of the lack of

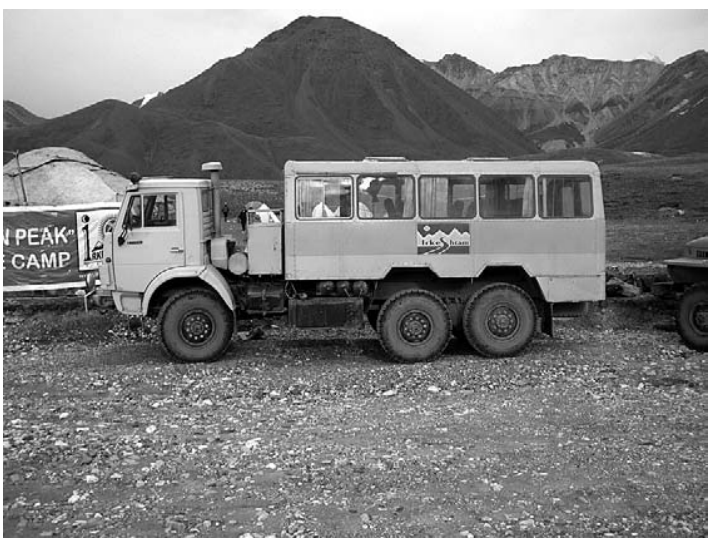

Photo 5. Large vehicle to transport tourists from Osh to the Pamir-Alai area, Mt. Lenin Base Camp (Photo: Ochiai, 26 July 2008).

\section{tourism facilities, inappropriate usage of natural}

resources and residents' recognition of the fact that foreign tourists can only come via international tour/trekking companies. Only a small portion of the tourism income is pocketed by some of the families in Sary-Tash, Sary-Mogol and Kashka-Suu. The local tourism-related organizations, if created, will minimize the monetary leakage. If such tourism-related organizations aim at ecotourism development, they eventually can augment the sustainability of the natural resources.

\section{Concluding remarks}

This study examined the current status of tourism in the Pamir-Alai Mountains, an area hitherto neglected by past tourism studies. The interview survey revealed that the eastern and central areas in the Alai Valley have primitive, small-scale tourism. The questionnaire survey $(\mathrm{N}=354)$ found that more than $90 \%$ of the respondents desire tourism infrastructure development in the area. Climbing and trekking tourism in the Mt. Lenin Base Camp area were active even in the Soviet times and are still the most important tourism activity. Tourism in this area, however, is led by foreign tour/ trekking companies and does not provide economic benefits to the local residents. Newly created yurts and homestays in Sary-Tash and Sary-Mogol also yield little benefit and this income too is limited to few families. Although most residents believe that the construction of a local airport and hotels and the improvement of the region's roads are effective tourism development measures, it is suggested that local tourism-related organizations be established before development by outsiders is allowed. 
This will minimize the monetary leakage of the income generated by tourism. The involvement of local residents can lead to ecotourism development, which will strengthen the sustainable use of natural resources.

\section{Acknowledgements}

This study was undertaken in cooperation with the UNU/GEF/UNEP PALM Project. We thank the National Center for Mountain Regions Development of the Kyrgyz Republic; Prof. A. Aidaraliev, President of the International University of Kyrgyzstan; Dr. Libor Jansky and Ms. Nevelina Pachova of the United Nations University, Bonn; and Mr. Oljobai Kutbidin Andarov, former mayor of the Kashka-Suu village for the logistic supports. We also thank the local residents, especially teachers at the seven schools in the Alai Valley for their help in survey in the field. This study was funded by the Grant-in-Aid for Scientific Research (Grant Nos. 17401002 and 20251001), and the Fukutake Science and Culture Foundation, Tokyo.

\section{References}

AGRECO Consortium (2007): Support to the Establishment of the Pamir-Alai Transboundary Conservancy Area (PATCA) between Kyrgyzstan and Tajikistan Inception Report-April 2007. AGRECO Consortium.

Anarbaev, M.(2007): State Policy on Sustainable Development of Distant and Mountain Regions of the Kyrgyz Republic: By Example of Kashka-Suu Ayil Okmotu. Master's Thesis submitted to the Academy of Management under the President of the Kyrgyz Republic. [in Russian]

Anarbaev, M. and Watanabe, T.(2008): Tourism in the Pamir-Alai Mountains, southern Kyrgyz Republic. Chiri (Geography), 55 (1), 56-59. [in Japanese]

Azykova, E.K.(2002): Geographical and landscape characteristics of mountain territories. In: Chokoeva, Ch.A., Hafizova, G.I., and Minnko, D.A. (eds.) Mountains of Kyrgyzstan, Technologiya Publishing House, Bishkek, $15-22$

Baird, D.R.(2008): Support to the Establishment of the Pamir-Alai Transboundary Conservancy Area (PATCA) between Kyrgyzstan and Tajikistan: Biodiversity Information Management System and Geographic Information System. Mission Report, 3.

CDE [Centre for Development and Environment] (2005): Synthesis Report. Baseline Survey on Sustainable Land Management in the Pamir-Alai Mountains. CDE, University of Bern and the United Nations University.
Hannam, I. (2006): Sustainable Land Management in the High Pamir and Pamir Alai Mountains GEF PDF-B Project. Synthesis Report.

Iwata, S. (2008): What kind of place are the Pamirs?: Extent, landforms and environments. Chiri (Geography), 53 (1), 18-29. [in Japanese]

Jansky, L. and Pachova, N.I.(2006): Towards sustainable land management in mountain areas in Central Asia. Global Environmental Research, 10, 99-115.

KCBTA [Kyrgyz Community Based Tourism Association] (2006): Community Based Tourism Guidebook 2006. KATOS/KCBTA, Bishkek.

Sawagaki, T. (2008): Climbing Mt. Lenin. Chiri (Geography), 55 (1), 42-46. [in Japanese]

Schillhorn van Veen, T.W.(1995): The Kyrgyz sheep herders at a crossroads. Pastoral Development Network Series, 38, 1-14.

Schneider, A. and Stadelbauer, J.(2008): Diversity in mountain tourism: the example of Kyrgyzstan. Colloquium Geographicum, 31, 12-37.

Watanabe, T. and Kasirov, K.(2007): Values and management of Tajik National Park in the Republic of Tajikistan. Kokuritsu Kouen (National Parks), No. 651, 26-28. [in Japanese]

Watanabe, T., Anarbaev, M., and Iwata, S. (2008): Protected area and tourism development in the Kyrgyz Republic. Geographical Studies, 83, 29-39. [in Japanese] 